\title{
ANALISIS SISTEM INFORMASI AKUNTANSI ATAS PELAKSANAAN FUNGSI PENJUALAN PADA PT. SURACO JAYA ABADI MOTOR
}

\author{
Nur Fatwa Basar \\ Sekolah Tinggi Ilmu Ekonomi Tri Dharma Nusantara Makassar \\ nurfatwabasar@gmail.com
}

\begin{abstract}
The purpose of this study is to determine the application of accounting information systems to the sales function at PT. Suraco Jaya Abadi Motor using questionnaire. Types of data are qualitative data and quantitative data and data sources used are primary data and secondary data. Methods of data collection is done by observation, interview and documentation. The analytical method used is descriptive qualitative. So generally based on observations, research results show that in 2015 Accounting Information Systems sales have been running effectively.
\end{abstract}

Keywords: Accounting Information System

\begin{abstract}
ABSTRAK
Tujuan penelitian ini adalah untuk mengetahui penerapan sistem informasi akuntansi terhadap fungsi penjualan pada PT. Suraco Jaya Abadi Motor dengan menggunakan kuesioner.Jenis data adalah data kualitatif dan data kuantitatif dan sumber data yang digunakan adalah data primer dan data sekunder.Metode pengumpulan data dilakukan dengan observasi, wawancara dan dokumentasi.Metode analisis yang digunakan adalah deskriptif kualitatif.Maka secara umum berdasarkan pengamatan, hasil penelitian menunjukkan bahwa pada tahun 2015 Sistem Informasi Akuntansi penjualan sudah berjalan dengan efektif.
\end{abstract}

Kata Kunci : Sistem Informasi Akuntansi

\section{PENDAHULUAN}

\section{Latar Belakang}

Seiring perkembangan lingkungan bisnis yang semakin kompetitif, peran teknologi sangat diperlukan dalam setiap aktivitas organisasi atau perusahaan. Hal ini sangat penting untuk meningkatkan daya saing perusahaan terutama pada penjualan, pembelian, rantai pasokan dan hubungan dengan konsumen. Sistem informasi akuntansi memberikan informasi dengan proses otomatis atau mempercepat ketersediaan informasi yang diperlukan bagi pembuat keputusan.

Perubahan yang pesat dalam bidang teknologi informasi, ekonomi, sosial budaya maupun politik mempengaruhi kondisi persaingan di dunia bisnis yang semakin lama semakin meningkat. Keadaan persaingan membuat para pelaku bisnis dan ekonomi harus menyesuaikan diri dan terus memperbaiki 
diri agar tetap dapat terus bersaing dengan kompetitornya. Untuk tetap dapat bersaing maka para pelaku bisnis dan ekonomi harus dapat melakukan berbagai transformasi kegiatan ekonominya menjadi seefektif dan seefisien mungkin.

Pada saat ini, semakin banyak perusahaan bergantung pada keandalan sistem informasi dalam menjalankan kegiatan operasionalnya. Era globalisasi menuntut perusahaan untuk memiliki sistem informasi yang memproses data yang diperoleh menjadi informasi yang berguna.

Kebutuhan akan adanya sistem informasi yang memadai hampir dirasakan di berbagai jenis bidang usaha. Dalam perusahaan dagang, sistem informasi sangat berperan dalam memberikan informasi yang akan dijadikan dasar pengambilan keputusan atas situasi yang dihadapi.

Sistem informasi akuntansi adalah kumpulan sumber daya seperti manusia dan peralatan yang diatur untuk mengubah data menjadi informasi. Salah satu kunci utama keberhasilan setiap perusahaan adalah tersedianya informasi akuntansi yang akurat, tepat waktu, dan terpercaya, informasi semacam ini hanya dapat dihasilkan melalui sistem informasi yang komprehensif dan tentu saja bertumpu pada standar pelaporan yang berlaku. Dengan adanya informasi dapat mendukung kegiatan operasi harian dengan mengumpulkan dan menyimpan data akuntansi dan membantu menjamin bahwa data organisasi diproses secara konsisten. Informasi yang dihasilkan oleh sistem informasi akuntansi tersedia dan digunakan oleh semua jenjang manajemen untuk melakukan perencanaan dan pengendalian kegiatan setiap organisasi.

Aspek penting dalam sistem informasi akuntansi adalah bahwa sistem itu berjalan dalam struktur pengendalian intern perusahaan. Struktur pengendalian intern menyarankan tindakan-tindakan yang harus diambil dalam perusahaan untuk mengatur dan mengarahkan aktivitas-aktivitas perusahaan. Informasi sangat diperlukan oleh manajemen untuk mengendalikan operasi dan keuangan yang dihasilkan oleh sistem informasi akuntansi. Salah satunya pengelolaan manajemen harus menjaga perusahaan dari kemungkinan kerugian yang diakibatkan oleh para pekerja-pekerja yang tidak efektif. Perusahaan dalam menjalankan usahanya sangat membutuhkan informasi yang relevan dan dapat dipercaya untuk mendukung proses pengambilan keputusan.

Fungsi penjualan dalam suatu perusahaan merupakan salah satu faktor 
yang sangat mempengaruhi kesuksesan dari perusahaan itu sendiri agar volume penjualan dapat ditingkatkan dibutuhkan informasi yang relevan dalam mendukung pengambilan keputusan dengan baik dan dengan adanya sistem informasi akuntansi yang memadai dalam fungsi penjualan dengan kata lain diperlukan informasi yang menunjang efektivitas pelaksanaan dalam meningkatkan penjualan.

\section{Rumusan Masalah}

Berdasarkan uraian pada latar belakang, maka rumusan masalah yang dapat dikemukakan dalam penelitian ini adalah apakah penerapan sistem informasi akuntansi terhadap fungsi penjualan pada PT. Suraco Jaya Abadi Motor sudah berjalan efektif.

\section{TINJAUAN PUSTAKA}

\section{Pengertian Sistem Informasi}

\section{Akuntansi}

Romney (2005:4) mengemukakan bahwa sistem informasi akuntansi adalah sumber daya manusia dan modal dalam organisasi yang bertanggung jawab untuk persiapan informasi keuangan dan informasi yang diperoleh dari mengumpulkan dan memproses berbagai transaksi perusahaan.
Siklus pemrosesan transaksi terdiri dari satu atau lebih sistem-sistem aplikasi. Sistem aplikasi memproses transaksitransaksi yang berkaitan secara logis. Siklus pendapatan perusahaan umumnya mencakup sistem aplikasi yang meliputi entri pesanan pelanggan, penagihan, piutang dagang dan pelaporan penjualan.

Siklus pengeluaran umumnya mencakup sistem aplikasi yang meliputi pemilihan dan permohonan pemasok, pembelian, hutang dagang dan penggajian. Siklus produksi mencakup sistem-sistem aplikasi yang meliputi pengendalian persediaan dan akuntansi kekayaan. Siklus keuangan perusahaan mencakup sistem aplikasi yang berkaitan dengan pengendalian dan manajemen kas, manajemen hutang, dan administrasi pensiun karyawan.

Meskipun secara alamiah berhubungan dengan keuangan, sebagian besar transaksi juga menghasilkan data statistik yang dibutuhkan manajemen. Penerimaan pesanan penjualan dan penerimaan barang dari pembekal adalah contoh dari transaksi-transaksi bisnis. Sistem informasi akuntansi dirancang dan diimplementasikan bukan hanya untuk memproduksi saldo buku besar dari laporan keuangan yang disajikan, tetapi juga menghasilkan beragam informasi 
manajemen dan operasional yang tidak berkaitan dengan akuntansi.

Tugas awal dari sistem informasi akuntansi adalah mengenali transaksi transaksi yang akan diproses oleh sistem. Seluruh pertukaran keuangan dengan entitas-entitas lain harus direfleksikan dalam laporan keuangan perusahaan. Sistem informasi akuntansi secara rutin memproses transaksi - transaksi moneter ini, seperti hanya juga dengan transaksitransaksi intern. Contoh dari kejadian ekonomi intern yang dapat diproses oleh sistem informasi akuntansi adalah pemindahan aktiva persediaan ke proses produksi, perhitungan penyusutan dan penyesuaian pada faktur-faktur pelanggan dan dokumen lainnya. Sistem informasi akuntansi juga memproses transaksitransaksi yang tidak secara langsung direfleksikan dalam saldo-saldo buku besar yang merupakan dasar dari laporan keuangan.

Model siklus transaksi perusahaan mencakup siklus kelima, yaitu siklus pelaporan keuangan. Siklus pelaporan keuangan bukan merupakan siklus operasi. Siklus itu memperoleh data akuntansi dan operasi siklus lain dan memproses data ini sesuai dengan cara untuk menghasilkan laporan keuangan. Penyajian laporan keuangan sesuai dengan standar akuntansi keuangan yang berlaku umum dan membutuhkan banyak penilaian dan ayat jurnal penyesuaian yang tidak secara langsung dihasilkan dari transaksi-transaksi. Penyusutan dan transaksi mata uang adalah dua contoh yang umum. Aktivitas-aktivitas seperti itu adalah bagian dari siklus pelaporan keuangan perusahaan. Konsep siklus pemrosesan transaksi menyediakan kerangka analisis aktivitas-aktivitas transaksi. Meskipun organisasi yang berbeda tidak mencakup sistem aplikasi yang sama dalam siklus pemrosesan transaksinya.

Definisi sistem informasi akuntansi menurut Krismiaji (2010:4), sistem informasi akuntansi adalah suatu sistem yang memproses data dan transaksi guna menghasilkan informasi yang bermanfaat untuk merencanakan, mengendalikan, dan mengoperasikan bisnis.

Dari beberapa pendapat, maka sistem informasi akuntansi mempunyai pengertian yang sama yaitu sekumpulan sumber daya yang bertujuan untuk mengumpulkan dan memproses data yang berhubungan dengan transaksi keuangan perusahaan untuk mendukung kegiatan administrasi perusahaan dalam melaksanakan aktivitas hari-harinya. 


\section{Jenis-jenis Sistem Informasi Akuntansi}

1. Sistem Pemrosesan Data - Electronic Data Processing (EDP) adalah pemanfaatan teknologi komputer untuk melakukan pemrosesan data transaksi-transaksi dalam suatu organisasi. EDP adalah aplikasi sistem informasi akuntansi paling dasar dalam setiap organisasi.

2. Sistem Informasi Manajemen (SIM)

Menguraikan penggunaan teknologi komputer untuk menyediakan informasi bagi pengambilan keputusan para manager. SIM menyediakan beragam informasi menyadari bahwa para manajer dalam organisasi menggunakan dan membutuhkan informasi dalam pengambilan keputusan sehingga sistem informasi berbasis komputer dapat menyediakan informasi yang bersangkutan kepada para manajer.

3. Sistem Penunjang KeputusanDecision Support System (DSS)

Dalam sistem penunjang keputusan, data diproses kedalam format pengambilan keputusan bagi kepentingan pemakai akhir. DSS menyarankan penggunaan model-model keputusan dan database khusus dan benar-benar terpisah dari sistem pemrosesan data.

4. Sistem Ahli - Export System (ES)

Export system adalah sistem informasi berbasis pengetahuan yang memanfaatkan pengetahuan tentang bidang aplikasi tertentu untuk bertindak seperti seorang konsultan ahli bagi para pemakainya.

5. Sistem Informasi Eksekutif Executive Information System (EIS)

Sistem informasi eksekutif dibuat bagi kebutuhan informasi strategik manajemen tingkat puncak.

\section{Komponen Sistem Informasi}

\section{Akuntansi}

Komponen sistem informasi akuntansi menurut Mardi (2011:6) terdiri dari lima komponen sistem informasi adalah sebagai berikut:

1. Sumber daya manusia merupakan bagian yang terpenting karena sumber daya manusia sebagai pemantau, pengoperasi, dan pengguna sistem informasi yang memberikan dampak kepada manajemen dan juga menentukan tingkat kesuksesan perusahaan.

2. Prosedur merupakan rangkaian aktivitas atau kegiatan yang dilakukan secara berulang-ulang dengan cara yang sama.

3. Data merupakan kumpulan data-data yang tersimpan dalam media penyimpanan dalam suatu perusahaan atau didalam komputer. 
4. Software adalah kumpulan-kumpulan dari program-program yang digunakan untuk menjalankan komputer, tanpa software computer tidak akan melaksanakan fungsinya.

5. Hardware merupakan peralatan fisik yang dapat digunakan untuk mengumpulkan, memasukkan, memproses, menyimpan dan mengeluarkan hasil pengelolah data dalam bentuk informasi.

\section{Elemen-elemen Sistem Informasi}

\section{Akuntansi}

Sujarweni (2015:3) mengemukakan bahwa sistem akuntansi adalah kumpulan elemen yaitu formulir, jurnal, buku besar, buku pembantu, dan laporan keuangan yang akan digunakan oleh manajemen untuk mencapai tujuan perusahaan. Elemen-elemen tersebut yaitu :

\section{Formulir}

Formulir adalah dokumen yang digunakan untuk mencatat terjadinya transaksi ekonomi di perusahaan. Dokumen dapat ditulis dalam secarik kertas untuk mendokumentasikan suatu transaksi ekonomi.. hardcopymaupun softcopy. Apabila formulir berupa hardcopy, penyimpanannya biasanya di rak ataupun di lemari. Jika formulir berupa softcopy, penyimpanannya berada di komputer.

\section{Jurnal}

Jurnal merupakan pencatatan berupa debet dan kredit yang bersumber dari formulir (dokumen dapat ditulis dalam secarik kertas untuk mendokumentasikan suatu transaksi ekonomi). Dalam jurnal ini data keuangan untuk pertama kalinya digolongkan dalam akun-akun dan dimasukkan dalam debet ataupun kredit.

\section{Buku Besar}

Buku besar (general ledger)adalah akun-akun yang dikelompokkan dan berdasarkan akun yang sudah dikelompokkan tadi dilakukan penjumlahan nilai uangnya. Buku besar merupakan buku catatan akhir yang merupakan kumpulan rekening-rekening neraca (real) dan rekening-rekening rugilaba (nominal) yang digunakan untuk meringkas data keuangan yang telah dicatat sebelumnya dalam jurnal. Rekening-rekening buku besar ini disediakan sesuai dengan elemen-elemen informasi yang akan disajikan dalam laporan keuangan.

4. Buku Pembantu

Buku pembantu (subsidiary ladger) adalah berfungsi untuk membantu merinci akun yang ada di buku besar. Buku pembantu ini terdiri dari akun pembantu yang merinci data keuangan 
yang tercantum dalam rekening tertentu dalam buku besar.

5. Laporan Keuangan

Laporan keuangan merupakan hasil akhir proses akuntansi, laporan keuangan terdiri dari neraca, laporan rugi laba yang digunakan perusahaan untuk melakukan pengambilan keputusan guna mencapai tujuan perusahaan. Laporan dapat berbentuk hasil cetak komputer dan tayangan pada layar monitor komputer.

Neraca menunjukkan kekayaan perusahaan pada periode tertentu, sedangkan rugi laba menunjukkan laba atau rugi perusahaan yang diperoleh selama periode tertentu.

\section{Tujuan Sistem Informasi Akuntansi}

Setiawati (2011:5) mengemukakan bahwa lingkup sistem informasi akuntansi dapat dijelaskan dari manfaat yang didapat dari informasi akuntansi. Manfaat atau tujuan sistem informasi akuntansi tersebut adalah sebagai berikut:

1. Mengamankan harta/ kekayaan perusahaan. Harta/kekayaan di sini meliputi kas perusahaan, persediaan barang dagangan, termasuk aset tetap perusahaan.Tidak ada pemilik yang senang jika uang perusahaan dicuri orang (entah itu karyawan maupun orang asing).Contoh, seorang memiliki usaha jasa persewaan
komik.Pemilik menempatkan seorang kasir ditempat persewaan tersebut. Setiap malam, pemilik akan mengambil kas hasil persewaan. Tentunya, pemilik tidak suka jika kasir tersebut tidak menyetorkan seluruh kas yang diterima.Kesempatan untuk mencuri uang perusahaan seperti ini dapat diminimalkan jika pemilik persewaan komik tersebut membangun sistem yang baik. Bagaimana caranya, akan dibahas lebih lanjut di ulasan-ulasan berikutnya.

2. Menghasilkan beragam informasi untuk pengambilan keputusan. Misal, pengelola toko swalayan memerlukan informasi mengenai barang apa yang diminati oleh konsumen. Membeli barang dagangan yang kurang laku berarti kas akan terjebak dalam persedian (yang sulit laku tersebut) dan berarti kehilangan kesempatan untuk membeli barang dagangan yang laku. Hal ini sangat penting, karena toko swalayan pada dasarnya tidak dapat mengambil margin laba yang tinggi (karena ketatnya persaingan antar toko swalayan). Jadi, toko swalayan lebih mengandalkan pada perputaran persediaan yang cepat. Oleh karena itu informasi mengenai persediaan yang laris merupakan 
kunci sukses sebuah swalayan. Informasi semacam ini dapat diakses dengan mudah jika toko swalayan tersebut membangun sistem informasi yang baik.

3. Menghasilkan informasi untuk pihak eksternal. Setiap pengelola usaha memiliki kewajiban untuk membayar pajak. Besarnya pajak yang dibayar tergantung pada omset penjualan (jika pengelola memilih menggunakan norma dalam perhitungan pajaknya) atau tergantung pada laba rugi usaha (jika pengelola memilih untuk tidak menggunakan norma dalam perhitungan pajaknya). Tanpa sistem yang baik, bisa jadi pengelola kesulitan untuk menentukan besarnya omset dan besarnya laba rugi usaha.Selain untuk kepentingan perpajakan, adakalanya pengelola usaha juga terlibat dengan kegiatan utang piutang dengan bank atau koperasi simpan pinjam. Bank membutuhkan informasi omset dan laba rugi usaha untuk memutuskan besarnya utang yang akan diberikan

4. Menghasilkan informasi untuk penilaian kinerja karyawan atau divisi. Sistem informasi dapat juga dimanfaatkan untuk penilaian kinerja karyawan atau divisi. Sebagai contoh, pengelola toko swalayan dapat memanfaatkan data penjualan untuk menilai kinerja kasir.Kasir mana yang lebih cepat dan lebih cermat dalam melayani pelanggan.Apresiasi pada karyawan yang rajin berguna untuk memotivasi karyawan dan meminimalkan sikap malas-malasan di tempat kerja.

5. Menyediakan data masa lalu untuk kepentingan audit. Data yang tersimpan dengan baik sangat memudahkan proses audit (pemeriksaan). Satu hal yang penting, audit bukan eksklusif milik perusahaan publik. Semua perusahaan mesti siap untuk menghadapi pemeriksaan (sekalipun perusahaan perseorangan), karena kantor pajak punya wewenang untuk melakukan pemeriksaan terhadap wajib pajak. Jadi, tidak ada alasan bagi satu kegiatan usaha untuk mendapat perkecualian bebas dari pemeriksaan. Benar, belum tentu dalam lima tahun, perusahaan kena giliran diperiksa, tetapi tidak ada salahnya jika perusahaan selalu siap dengan data dan dokumen pendukung yang rapi sehingga mudah diaudit. Tambahan lagi, sekalipun tidak ada pemeriksaan dari kantor pajak, baik jika sekali waktu perusahaan diaudit oleh pihak eksternal. Audit semacam ini berguna 
bagi perusahaan untuk evaluasi diri, serta untuk menimbulkan kewaspadaan (kehati-hatian) pada karyawan administrasi bahwa apa yang mereka kerjakan suatu saat akan diperiksa oleh pihak lain.

6. Menghasilkan informasi untuk penyusunan dan evaluasi anggaran perusahaan. Anggaran merupakan alat yang sering digunakan perusahaan untuk mengendalikan pengeluaran kas. Anggaran membatasi pengeluaran seperti yang telah disetujui dan menghindari pengeluaran yang seharusnya tidak dikeluarkan, dan berapa besarnya. Anggaran bermanfaat untuk mengalokasikan dana yang terbatas. Anggaran berperan dalam menerapkan skala prioritas pengeluaran sesuai dengan tujuan perusahaan.Sistem informasi dapat dirancang untuk mempermudah pengawasan pengeluaran, apakah sudah melewati batas anggaran yang telah disetujui.

7. Menghasilkan informasi yang diperlukan dalam kegiatan perencanaan dan pengendalian. Selain berguna untuk membandingkan informasi yang berkaitan dengan anggaran dan biaya standar dengan kenyataan seperti yang telah dikemukakan sebelumnya, data historis yang diproses oleh sistem informasi dapat digunakan untuk meramal pertumbuhan penjualan dan aliran kas atau untuk mengetahui tren jangka panjang beserta korelasinya.

Fungsi dan Peranan Sistem Informasi Akuntansi

Menurut Wilkinson (2007 : 11) dalam Dianah (2013:21) dalam bukunya yang berjudul sistem informasi akuntansi mengemukakan bahwa setiap informasi akuntansi melakukan lima fungsi, yaitu pengumpulan data, pengolahan data, manajemen data, pengendalian dan pengamanan data dan penyediaan informasi.

Peranan sistem informasi akuntansi bagi pihak eksternal perusahaan jelas sangat penting sebagai penghasil informasi dalam bentuk laporan keuangan, seperti neraca, laporan rugi-laba, laporan perubahan posisi keuangan, serta laporan arus kas, yang diterbitkan secara periodik laporan tersebut sangat bermanfaat bagi pihak eksternal perusahaan, sehingga mereka dapat mengambil keputusan yang perusahaan, sehingga mereka dapat mengambil keputusan yang berkaitan dengan kepentingan terhadap perusahaan. 
Bagi pihak eksternal perusahaan peranan sistem informasi akuntansi jauh lebih penting lagi karena bersama- sama dengan sistem informasi lainnya menyediakan informasi yang dibutuhkan oleh manajemen sebagai dasar pengambilan keputusan.

\section{Karakteristik Kualitatif Sistem Informasi Akuntansi}

Hall (2009:178) mengemukakan bahwa apa pun bentuk fisiknya, informasi yang berguna memiliki karakteristik sebagai sebagai berikut:

\section{Relevan}

Isi laporan atau dokumen harus sesuai dengan tujuan. Laporan atau dokumen dapat mendukung keputusan manajer atau pekerjaan staf administrasi. Telah dibahas bahwa hanya data yang relevan dengan tindakan pengguna yang memiliki nilai informasi. Oleh karenanya, sistem informasi harus hanya menyajikan data yang relevan dalam laporan yang dihasilkannya.

\section{Ketepatan Waktu}

Umur informasi adalah faktor yang penting dalam menentukan nilai kegunaannya. Contohnya, jika seorang manajer membuat keputusan harian untuk membeli persediaan dari seorang pemasok berdasarkan laporan status persediaan, maka informasi dalam laporan tersebut harus tidak boleh lebih dari satu hari umurnya.

3. Akurasi

Informasi harus bebas dari kesalahan yang penting. Akan tetapi, penting atau tidak adalah konsep yang sulit untuk diukur. Konsep ini tidak memiliki nilai tertentu; ini adalah konsep yang tergantung pada situasinya. Hal ini berarti bahwa, dalam beberapa situasi, informasi harus benar-benar akurat. Di situasi lainnya, tingkat akurasi dapat lebih rendah. Kesalahan yang penting terjadi ketika jumlah ketidakakuratan dalam informasi menyebabkan pengguna membuat keputusan yang salah atau gagal membuat keputusan yang dibutuhkan.

\section{Kelengkapan}

Tidak ada satu pun informasi penting untuk keputusan atau tindakan yang boleh hilang. Contohnya, laporan harusnya menyediakan semua perhitungan yang dibutuhkan serta menyajikan pesannya dengan jelas dan tidak ambigu.

\section{Ringkas}

Informasi harus terkumpul sesuai dengan kebutuhan pengguna. Manajer tingkat yang lebih rendah cenderung membutuhkan informasi yang sangat terperinci. Ketika arus informasi menuju ke atas di perusahaan ke manajemen 
puncak, maka akan menjadi makin ringkas.

\section{Pengertian Pengendalian Intern}

Mardi (2011:59) mengemukakan bahwa pengendalian intern merupakan suatu sistem yang meliputi struktur organisasi beserta semua mekanisme dan ukuran-ukuran yang dipatuhi bersama untuk menjaga seluruh harta kekayaan organisasi dari berbagai arah.

Bodnar (2005:8) pengendalian intern adalah tindakan-tindakan yang harus diambil dalam perusahaan untuk mengatur dan mengarahkan aktivitasaktivitas perusahaan oleh manajemen untuk mengendalikan operasi dan keuangan yang dari sistem informasi akuntansi.

Struktur pengendalian intern meliputi berbagai kebijakan dan prosedur yang ditetapkan guna memberikan arah yang jelas dan benar untuk pencapaian tujuan organisasi di masa depan. Berdasarkan pemanfaatan dari sistem yang menyediakan arah jelas dan benar, menyebabkan para pihak yang terkait mengalami kesulitan mendesain dan membuat sistem. Alasan yang menjadi kendala adalah terbentur dengan biaya yang mahal dan tidak seimbangnya antara biaya yang dikeluarkan dengan manfaat yang diperoleh. Struktur pengendalian intern menurut mardi (2011:60) adalah sebagai berikut :

a. Pengendalian Preventif

Pengendalian preventif didesain untuk langkah awal mencegah terjadinya berbagai tindakan yang dapat merugikan terjadinya tindakan yang merugikan perusahaan harus diatasi dengan persiapan yang matang melalui pengendalian preventif, sistem harus didesain dengan canggih untuk mengatasi serangan dari luar, tidak ada satu butir debu pun yang bisa masuk kedalam. Oleh karena itu, kemampuan petugas yang memiliki otoritas dibidangnya dapat melakukan kerja sama, terutama dalam kesamaan persepsi antara tindakan dengan aturan yang dibuat. Pengendalian preventif dilakukan supaya sistem tersebut dapat menjaga kerahasiaan dokumen sumber, beserta format-format yang dibuat.

b. Pengendalian Deteksi

Pengendalian deteksi merupakan pertahanan lapis kedua, pertahanan ini merupakan kejadian yang diakibatkan lolosnya serangan akibat pertahanan garis pertama yang tidak kuat. Oleh karena itu, pada bagian ini dibutuhkan ketelitian dan mengidentifikasi kejadian yang diakibatkan lolosnya serangan dari baris pertama diatas. Dibutuhkan peralatan, teknik dan prosedur yang jelas untuk 
mengatasi serangan tersebut. Periksalah prosedur standar apakah sudah berjalan dengan baik. Jika belum berjalan dengan baik, perbaiki secepatnya agar serangan yang lebih berat tidak terulang.

c. Pengendalian Koreksi

Pengendalian koreksi adalah proses memperbaiki kesalahan-kesalahan yang diakibatkan pertahanan lapis kedua tidak bisa mengatasi serangan yang merugikan. Oleh karena itu, secepatnya melakukan ralat secara hati-hati supaya sistem lain yang sedang berproses tidak mengalami gangguan, tindakan koreksian yang dilakukan tidak semata terfokus pada satu metode saja, tetapi menggunakan berbagai cara.

Adapun komponen pokok sistem pengendalian intern menurut Mardi (2011:62) adalah sebagai berikut:

a. Lingkungan Pengendalian merupakan persepsi perorangan dalam perusahaan tentang pentingnya pengendalian intern. Pimpinan perusahaan harus menunjukkan komitmennya terhadap pelaksanaan kontrol yang ketat dan kebijakannya secara sadar dan langsung diikuti oleh para bawahan. Suasana seperti ini merupakan lingkungan pengendalian yang efektif diterapkan dalam perusahaan. b. Aktivitas Pengendalian merupakan sekumpulan peraturan dan kebijakan yang telah ditetapkan dan digariskan untuk tujuan keberhasilan pengendalian dalam perusahaan. Aktivitas pengendalian pada dasarnya berbentuk pengendalian yang menggunakan pendekatan berbasis teknologi informasi dan pengendalian yang menggunakan pendekatan manual.

c. Penilaian Risiko merupakan instrumen penting dalam mengontrol bisnis perusahaan. Sistem pengendalian harus dievaluasi secara berkala efektivitasnya. Organisasi harus melakukan penilaian risiko untuk mengidentifikasi, menganalisis dan mengatur risiko yang relevan dengan pelaporan keuangan.

d. Kualitas Informasi dan Komunikasi merupakan kualitas informasi yang dihasilkan memberi dukungan penuh keberhasilan pimpinan membuat keputusan bisnis, informasi laporan yang dihasilkan SIA membantu pimpinan membuat keputusan terkait dengan operasi perusahaan serta bagaimana informasi keuangan yang dibuat dapat dikomunikasikan secara cepat dan akurat. Informasi keuangan yang dihasilkan harus akurat, didukung data dan fakta sehingga 
memiliki nilai penting untuk dijadikan sebagai pengambilan keputusan.

e. Pengawasan merupakan proses penilaian kualitas kerja struktur pengendalian intern dalam bekerja. Tingginya kinerja yang diraih tidak lepas dari penerapan teknik pengawasan. Pengawasan yang efektif dilakukan untuk meningkatkan kinerja bukan untuk menghilangkan kinerja dan prestasi perusahaan.

\section{Sistem Informasi Akuntansi terhadap}

\section{Fungsi Penjualan}

Fungsi penjualan menurut Romney (2005:31) fungsi penjualan adalah cara yang akurat dan efisien memproses pesanan pelanggan memastikan bahwa perusahaan dibayar untuk semua penjualan baik secara kredit maupun tunai dan bahwa semua penjualan itu sah serta untuk meminimalkan hilangnya pendapatan akurat dari manajemen persediaan yang kurang akurat.

Goerge (2009:25), mengemukakan bahwa fungsi penjualan bertanggungjawab atas penerimaan order dari langganan dan meneruskan order tersebut ke fungsi produksi. Jika order dari langganan ditulis dari formulir yang disediakan oleh perusahaan, order langganan langsung dapat diserahkan oleh fungsi penjualan ke fungsi produksi untuk dapat segera diproses. Jika dari langganan belum berisi informasi yang lengkap, fungsi penjualan berkewajiban untuk menambahkan informasi yang kurang atau menulis kembali dalam surat order produksi yang berisi informasi lengkap bagi kepentingan fungsi produksi. Fungsi penjualan melayani order dari pelanggan berdasarkan persediaan produk jadi yang ada di gudang.

Menurut Sarosa (2009:66), dalam sebuah organisasi atau perusahaan sistem informasi akuntansi penjualan terbentuk dari dua sistem yang saling berhubungan yaitu:

a. Sistem pemasaran dan pengiriman

Fungsi dari sistem pemasaran yaitu lebih menekankan padapenjualan. Terdapat tiga dokumen yang diperhatikan dalam sistem pemasaran yaitu:

1. Sales order, termasuk didalamnya nomor seri perusahaan dan nomor purchase order pelanggan. Ini merupakan nomor silang yang menggabungkan dokumen-dokumen pembeli dan penjual, dan menetapkan kontrak.

2. Sales order acknowledgement, salinan dokumen pengiriman dan pemberitahuan (surat tanda bukti) bahwa barang telah dikirim dengan cara mencocokkan dengan salinan 
pesanan penjualan yang telah dikirim dan melakukan sejumlah pemeriksaan atas data yang dimasukkan dengan membandingkan jumlah yang ada dalam pesanan penjualan

3. The customer and address record, mencatat nama dan alamat pelanggan untuk melengkapi pesanan penjualan dengan cara mencatat nomor rekening pelanggan, nomor produk dan jumlah serta tanggal pengiriman untuk mengakses catatan yang tepat sesuai dengan file pelanggan.

b. Sistem penagihan dan pengumpulan

Fungsi sistem penagihan dan pengumpulan data harus dirancang sedemikian rupa untuk mendukung aktivitas pengumpulan yang menjamin pengingkatan laba dan meminimalkan kerugian hutang. Dokumen sumber yang diperlukan agar sistem dapat berfungsi dengan tepat antara lainsales order, sales invoice, customer statement dan daftar penghapusan hutang.

\section{METODE PENELITIAN}

\section{Jenis dan Sumber Data}

1. Jenis Data

a. Data kualitatif, analisis yang dilakukan terhadap data-data yang non angka seperti hasil wawancara atau catatan laporan bacaan dan bukubuku. b. Data kuantitatif, analisis yang dilakukan terhadap data yang berbentuk angka dan diperoleh dalam bentuk laporan keuangan.

2. Sumber Data

a. Data primer, yaitu data yang diperoleh langsung dari dari hasil observasi dan wawancara langsung dengan pihak yang berwenang.

b. Data sekunder, yaitu data yang diperoleh dari dokumen-dokumen dan bahan tertulis, efektif yang berasal dari dalam perusahaan maupun dari luar perusahaan yang berhubungan dengan masalah yang akan dibahas.

\section{Metode Pengumpulan Data}

Metode penelitian adalah cara yang sistematis dan sangat penting dengan tujuan untuk memecahkan rumusan masalah dalam suatu penelitian. Untuk memperoleh data yang diperlukan dalam penelitian ini, maka penulis menggunakan metode pengumpulan data sebagai berikut:

1. Penelitian kepustakaan (Library research)

Penelitian ini dimaksudkan untuk memperoleh data sekunder yang menjadi landasan teori guna mendukung data-data yang diperoleh selama penelitian. Data ini bersumber dari buku dan referensi lainnya yang berkaitan dengan penelitian. 


\section{Penelitian Lapangan (Field research)}

Penelitian ini dilakukan untuk memperoleh data primer, yaitu dengan melaksanakan penelitian langsung ke obyek penelitian untuk memperoleh data melalui:

a. Wawancara. Metode ini digunakan untuk mendapatkan data dengan cara mengerjakan pertanyaan kepada unit organisasi atau pihak-pihak perusahaan untuk memperoleh data mengenai sistem informasi akuntansi penjualan pada PT. Suraco Jaya Abadi Motor.

b. Observasi. Dalam menggunakan metode observasi, cara yang paling efektif adalah melakukan peninjauan langsung untuk

mengamati sistem yang ditempuh pada PT. Suraco Jaya Abadi Motor.

c. Dokumentasi. Metode ini digunakan untuk memperoleh data mengenai dokumen yang digunakan perusahaan dalam pelaksanaan sistem informasi terhadap fungsi penjualan dan data berupa gambaran umum perusahaan, prosedur penjualannya. Struktur organisasi serta tugas dan tanggung jawabPT. Suraco Jaya Abadi Motor.

d. Kuesioner yaitu berupa daftar pertanyaan yang disebarkan kepada responden yaitu karyawan bagian penjualan.

\section{Populasi dan Sampel}

Yang menjadi populasi dalam penelitian ini adalah karyawan PT. Suraco Jaya Abadi Motor yang berjumlah 35 orang.

Peneliti tidak mengambil semua populasi yang ada, maka peneliti hanya mengambil sampel pada karyawan PT. Suraco Jaya Abadi Motor khususnya pada bagian penjualan sebanyak 20 orang.

\section{Metode Analisis}

Untuk menganalisis data yang diperoleh, metode yang akan digunakan dalam penulisan ini adalah analisis deskriptif kualitatif, yaitu menggunakan kuesioner dengan memperhatikan komponen-komponen sistem informasi akuntansi menurut Mardi terdiri dari lima komponen sistem informasi yaitu: sumber daya manusia, prosedur, data, software, dan hardware.

Berdasarkan hasil kuesioner yang diberikan kepada responden melalui hasil analisis dengan menggunakan principal komponen analisis, kemudian skor hasil perolehan kuesioner diolah. Adapun langkah-langkah dalam melakukan analisis adalah sebagai berikut:

a. Setiap indikator/sub variabel yang dinilai responden, diklasifikasikan ke dalam lima alternatif jawaban dengan menggunakan skala ordinal yang 
menggambarkan peringkat jawaban dan setiap indikator diberi skor 1 sampai dengan 5 .

b. Dihitung total skor setiap variabel/sub variabel yaitu jumlah skor

seluruh skor indikator variabel untuk semua responden.

c. Dihitung skor setiap variabel/sub variabel yaitu rata-rata daritotal skor.

d. Untuk mendeskripsikan jawaban responden juga digunakan statistik deskriptif seperti didistribusi frekuensi dan ditampilkan dalam bentuk tabel.

Untuk menjawab deskripsi tentang masing-masing variabel penelitian ini digunakan rentang kriteria penilaian. Selanjutnya untuk menetapkan peringkat dalam setiap variabel penelitian dapat dilihat dari perbandingan antara skor aktual dengan skor ideal. Skor aktual diperoleh melalui hasil perhitungan seluruh pendapat responden sesuai klasifikasi bobot yang diberikan (1, 2, 3, 4, 5). Sedangkan untuk skor ideal diperoleh melalui perolehan prediksi nilai tertinggi dikalikan dengan jumlah kuesioner lalu dikalikan dengan jumlah responden.

Untuk masing-masing variabel terdiri dari 5 dimensi (bobot) dengan 20 item kuesioner dan jumlah responden sebanyak 20 orang.

\section{HASIL PENELITIAN DAN PEMBAHASAN}

\section{Penerapan Sistem Informasi}

Akuntansi Penjualan Pada PT. Suraco

\section{Jaya Abadi Motor}

Dalam rangka memenuhi kebutuhan manajemen penjualan dalam hal ini bagian pembekalan akan Sistem Informasi Akuntansi untuk tujuan pengendalian internal perusahaan. Maka perusahaan ini sejak tahun 2012 mulai menerapkan sistem informasi terkomputerisasi untuk menggantikan sistem informasi manual.Salah satu sistem informasi yang penting diperlukan oleh perusahaan dagang dan industri adalah informasi tentang penjualan PT. Suraco Jaya Abadi Motor Makassar sebagai perusahaan swasta yang bergerak dibidang perdagangan motor, spare part (alat-alat motor) yang membutuhkan sistem informasi tentang penjualan guna kelancaran operasional perusahaan.

1. Sumber Daya Manusia

Bagian-bagian yang terlibat dalam pemrosesan transaksi penjualan pada PT. Suraco Jaya Abadi Motor antara lain:

a. Sales Counter/Sales Fource dari departemen penjualan yang menerima pesanan dari user langsung dan menjelaskan detail keunggulan motor 
sesuai kebutuhan konsumen, harga dan syarat-syarat pembelian.

b. Staf administrasi menyelesaikan penginputan data

c. Kasir menerima pembayaran dari konsumen

d. Kepala cabang menandatangani berkas pembelian

2. Prosedur

Metode pemrosesan data PT. Suraco Jaya Abadi Motor menggunakan metode on line setiap transaksi yang terjadi langsung dimasukkan ke dalam data base dan sekaligus diproses dan disimpan dalam basis data.

\section{Software}

Dalam menjalankan usahanya PT. Suraco Jaya Abadi Motor menerapkan tiga konsep pelayanan yaitu: sales, service,spare part. Aplikasi yang diterapkan pada sistem informasi akuntansi terkompensasi dibagian penjualan PT. Suraco Jaya Abadi Motor adalah menggunakan sistem data base dengan program aplikasi Customer Relationship Manajement (CRM) dan aplikasi Exodus yang dirancang sesuai dengan kebutuhan dan jenis usaha yang dijalankan oleh PT. Suraco Jaya Abadi Motor.

4. Data

Catatan akuntansi dalam sistem akuntansi berdasarkan komputer disajikan dalam bentuk file-file magnetis dalam tiga jenis file yaitu: file induk (master file) adalah data yang relatif tidak berubah untuk jangka waktu yang lama. File transaksi (transaction file) adalah data yang dimasukkan kedalam basis data atas proses transaksi sehari-hari dan file arsip adalah data tentang transaksi masalah yang dipertahankan untuk referensi yang akan datang.

Penerapan sistem informasi akuntansi dengan menggunakan pendekatan data base diperlukan sebagai solusi dan masalah-masalah dalam sistem tradisional seperti hambatan diantara unit-unit organisasi untuk kepentingan pemakainya yang mengakibatkan pemborosan data dan masalah-masalah manajemen penting lainnya.

Untuk melihat sejauh mana sistem informasi akuntansi meningkatkan sistem pengendalian intern, penulis melihat dari perspektif karyawan, perspektif ini melihat sejauh mana penggunaan sistem informasi akuntansi dapat mencegah mendeteksi dan mengoreksi kesalahan yang mungkin terjadi, meningkatkan efektivitas dan efisiensi dalam bekerja sehingga diharapkan mampu meningkatkan pengendalian intern perusahaan.

5. Hardware 
Dokumen dalam proses transaksi penjualan yang digunakan perusahaan untuk konsumen adalah:

a. Surat pemesanan kendaraan digunakan sebagai tanda bahwa konsumen memang memesan kendaraan kepada perusahaan tersebut.

b. Faktur penjualan, diterbitkan pada saat konsumen memasukkan pesanan ke perusahaan kemudian dikirimkan ke kantor pusat untuk pembuatan STNK dan BPKB

c. Surat jalan sebagai bukti pengiriman barang kepada konsumen sekaligus sebagai bukti realisasi transaksi bagi konsumen.

d. Formulir picking list, tembusan faktur yang berfungsi sebagai slip pembungkus yang ditempelkan diatas pembungkus barang sebagai alat identifikasi barang oleh bagian pengiriman barang.

\section{Sistem Akuntansi Penjualan dan}

\section{Aktivitas Pengoperasian Perusahaan} yang dilakukan pada PT. Suraco Jaya

\section{Abadi Motor}

Sistem akuntansi penjualan yang dilakukan pada PT. Suraco Jaya Abadi Motor adalah sistem penjualan tunai dan penjualan kredit.Sistem ini yang digunakan untuk menangani transaksi baik barang maupun jasa. Dalam penjualan kredit jika order dari pelanggan telah dipenuhi dengan pengiriman barang untuk jangka waktu tertentu perusahaan memiliki piutang. Dalam transaksi penjualan tunai barang dan jasa baru diserahkan oleh bagian pengiriman kepada pembeli jika bagian kasir telah menerima uang dari pembeli.

Rangkaian sistem akuntansi dan aktivitas pengoperasian perusahaan yang dilakukan padaPT. Suraco Jaya Abadi Motor.Langkah-langkah yangdilakukan pada PT. Suraco Jaya Abadi Motor. Langkah-langkah yang dilakukan adalah sebagai berikut:

Proses penjualan dimulai dari counter sales dari departemen penjualan yang menerima pesanan dari user yang mempunyai fasilitas kredit di PT. Suraco Jaya Abadi Motor, setelah sales counter menjelaskan keunggulan motor dan harga kepada pelanggan, pelanggan melengkapi pesanan penjualan yang mengungkapkan informasi-informasi penting seperti nama dan alamat, penjualan tunai cukup melampirkan fotocopy KTP, sedangkan penjualan kredit melampirkan fotocopy KTP suami istri jika sudah berkeluarga, rekening pembayaran seperti listrik, air, PBB dan telpon serta kartu keluarga sedangkan yang belum berkeluarga melampirkan fotocopy KTP penjamin, 
jika sudah memiliki penghasilan tetap tetapi belum berkeluarga namanya pemohon tunggal. Setelah menyimpan dokumen pesanan penjualan, petugas arsip penjualan akan menyimpan satu salinan dari dokumen tersebut sebagai arsip pesanan pelanggan dan diinput ke dalam data penjualan sebagai referensi dimasa yang akan datang.

Setelah salescounter menjelaskan semua dan sudah deal dengan harga pelanggan kemudian diarahkan ke bagian administrasi untuk kelengkapan berkas menginput data seperti nomor telepon, pekerjaan, penghasilan perbulan dan sumber dana, setelah itu pelanggan diarahkan ke bagian kasir untuk pembayaran.

Melakukan transaksi persetujuan yang mana berhubungan dengan pemeriksaan kelayakan pemberian kredit kepada pelanggan.Dalam memutuskan sifat/jenis pemeriksaan pemberian kredit sangat bergantung pada keadaan saat terjadinya penjualan. Hasil persetujuan tersebut akan mengakibatkan pendistribusian salinan pesanan penjualan yang lainnya ke berbagai departemen secara serentak dan keluarnya faktur penjualan.

Pengiriman barang menandai berakhirnya kejadian ekonomi dan merupakan saat dimana pelanggan dapat
ditagih.Penagihan sebelum pengiriman dilaksanakan dapat meningkatkan ketidaktepatan dalam pembukuan dan ketidakefisienan dalam beroperasi.

Sebelum menerima barang departemen pengiriman menerima salinan dokumen pengiriman dan surat jalan yang berasal dari departemen penjualan. Dokumen pengiriman bersama dengan barang dikirim kepada pelanggan.Surat jalan memberikan informasi kepada departemen.

\section{Analisis Sistem Informasi Akuntansi}

\section{Penjualan pada PT. Suraco Jaya Abadi}

\section{Motor}

Salah satu upaya yang dilakukan oleh setiap perusahaan dalam penyajian informasi akuntansi pada suatu perusahaan khususnya pada PT. Suraco Jaya Abadi Motor adalah dengan melakukan penilaian untuk mengetahui sistem informasi akuntansi penjualan PT. Suraco Jaya Abadi Motor dilakukan dengan membandingkan antara teori dengan penelitian yang dilakukan dengan menggunakan kuesioner dengan mengajukan beberapa pertanyaan mengenai komponen-komponen sistem informasi akuntansi.

1. Sumber daya manusia

Berdasarkan responden mengenai komponen sumber daya manusia, 
terdapat $88,5 \%$. Jawaban responden berada pada kondisi sangat efektif.Untuk menghindari adanya kecurangan di dalam perusahaan khususnya pada bagian penjualan yang dilakukan oleh karyawan dan untuk mendapatkan karyawan yang jujur dan kompeten.Manajemen PT. Suraco Jaya Abadi Motor pada saat penerimaan karyawan terlebih dahulu melakukan seleksi dan beberapa tes sebelum menerima karyawan tersebut dan selanjutnya diberikan pelatihan berupa training selama 3 bulan.Dan jika selama 3 bulan itu dianggap sudah mapan maka baru diterima sebagai karyawan tetap.

Dalam memudahkan untuk menjalankan aktivitas penjualan terutama pada penjualan kredit.Perusahaan melakukan pemisahan fungsi masingmasing.Bagian pada orang yang berbeda.Fungsi penjualan kredit diserahkan pada bagian penjualan kredit sedangkan fungsi pencatatan diserahkan pada bagian akuntansi.Selanjutnya untuk nota tagihan diserahkan kepada kolektor dan selanjutnya dilaporkan kepada manajer.

PT. Suraco Jaya Abadi Motor memberikan kebijakan bagi karyawan yang telah bekerja sesuai dengan aturan dan juga dilihat dari lamanya bekerja.

Perusahaan memberikan bonus bagi karyawan yang melakukan penjualan dalam jumlah besar sedangkan bagi karyawan yang melakukan tindakan yang dapat merugikan perusahaan maka akan diberikan sanksi.

2. Prosedur

Berdasarkan jawaban responden mengenai komponen prosedur terdapat 91,4\% berada pada kondisi sangat efektif. Prosedur sistem informasi akuntansi yang diterapkan merupakan suatu petunjuk yang dicatat yang mengatur suatu aktivitas perusahaan.Dalam hal ini PT. Suraco Jaya Abadi Motor dalam melakukan penjualan dilengkapi dengan beberapa dokumen penting seperti IDcart, nota penjualan, nota service dan nota pembelian.Dan pada penjualan tunai dilengkapi dengan kwitansi penjualan.

Dalam hal pengeluaran barang pihak perusahaan memberikan tugas kepada bagian gudang untuk memonitoring keluarnya barang setiap pengambilan barang dari gudang dilengkapi surat order pengiriman yang telah dikirim ke bagian gudang untuk menyiapkan jenis barang dengan jumlah barang seperti yang tercantum di dalam nota pengiriman agar menyerahkan ke bagian pengiriman dan bagian gudang mencatat barang yang dijual atau keluar pada kartu gudang.

Untuk menjalankan aktivitasnya PT. Suraco Jaya Abadi Motor melakukan 
penyebaran brosur dan memperkenalkan merek motor baru.Peruahaan memberikan kemudahan terhadap pelanggan dalam pemberian kredit pelanggan hanya menyiapkan berkas berupa fotocopy KTP, kartu keluarga dan rekening listrik dan sebelum melakukan transaksi penjualan terlebih dahulu melakukan peninjauan atau survey untuk mengetahui layak tidaknya untuk dilakukan pemberian kredit.

3. Data

Dari tabel diatas dapat diketahui pada komponen data atas jawaban responden terdapat $92,3 \%$ adalah berada pada kondisi sangat efektif. Adanya pemisahan fungsi pada transaksi penjualan yang dilakukan oleh PT. Suraco Jaya Abadi Motor untuk memberikan kemudahan apabila terdapat kesalahan dalam setiap transaksi.

4. Software

Dari tabel diatas dapat dilihat bahwa $91,5 \%$ hasil jawaban responden mengenai komponen software berada pada kondisi sangat efektif. Metode pencatatan dan pemrosesan data menggunakan metode online setiap transaksi langsung dimasukkan dalam basic data.

5. Hardware

Dari tabel diatas dapat dilihat bahwa terdapat $71 \%$ hasil jawaban responden mengenai komponen hardware yang berada pada kondisi efektif.Perusahaan membolehkan perangkat komponen hanya boleh diketahui dan digunakan hanya bagian yang bersangkutan serta kode yang digunakan adalah dengan menggunakan ID card.Pengendalian terhadap fasilitas komponen hanya pada karyawan tertentu saja.Yang diberikan otorisasi dalam hal penggunaan password.

\section{Penerapan Sistem pengendalian Intern} Penjualan pada PT. Suraco Jaya Abadi Motor

Dalam melakukan setiap aktivitas penjualan agar tidak terjadi kecurangan atau hal-hal yang dapat merugikan pada PT.Suraco Jaya Abadi Motor, maka pihak manajemen memerlukan adanya pengawasan internal perusahaan. Adapun penerapan pengendalian intern penjualan tersebut adalah:

1. Pengendalian Umum pada PT. Suraco Jaya Abadi Motor

a. Pengendalian Organisasi Pengendalian organisasi dapat tercapai bila dalam suatu perusahaan terdapat pembagian tugas dan tanggung jawab yang jelas untuk setiap bagian dari perusahaan pada PT. Suraco Jaya Abadi Motor pembagian tugas dan tanggung jawab 
ini didasarkan pada fungsi masingmasing bagian, yaitu:

1) Fungsi penjualan yang terpisah dari fungsi kredit. Pemisahan tersebut dilakukan PT.Suraco Jaya Abadi Motor untuk menciptakan pengecekan intern terhadap transaksi penjualan.Pada transaksi penjualan mempunyai kecenderungan menjual barang sebanyak-banyaknya. Oleh karena itu diperlukan adanya pengecekan intern terhadap status pelanggan sebelum transaksi penjualan tersebut dilaksanakan.Pada fungsi penjualan telah diberi wewenang untuk menolak pemberian kredit kepada pelanggan berdasarkan analisa riwayat pelunasan hutang yang dilakukan oleh pelanggan tersebut dimasa lalu. Pemisahan fungsi akuntansi dari fungsi penjualan kredit PT. Suraco Jaya Abadi Motor melakukan pemisahan fungsi dimaksudkan tidak terjadi kesalahan dalam aktivitas penjualan, dimana fungsi akuntansi melaksanakan pencatatan harus dipisahkan dari fungsi operasi yang melaksanakan transaksi penjualan dan dari fungsi kredit yang mengecek kemampuan pelanggan dalam melunasi kewajibannya dan sebagai pemberi otorisasi kredit

2) Pemisahan fungsi akuntansi dan fungsi penyimpanan Dalam hal ini PT. Suraco Jaya Abadi Motor melakukan pemisahan fungsi dimaksudkan untuk menjaga kekayaan perusahaan dan menjamin ketelitian dan keandalan data akuntansi perusahaan dengan kata lain apabila kedua sistem digabungkan fungsi akuntansi dengan fungsi penyimpanan akan membuka kesempatan bagi karyawan perusahaan untuk melakukan kecurangan dengan mengubah catatan akuntansi untuk menutupi kecurangan yang dilakukannya.

3) Transaksi dilaksanakan lebih dari satu orang atau lebih dari satu fungsi Pada PT. Suraco Jaya Abadi Motormelaksanakan setiap aktivitas penjualan harus dilaksanakan oleh masing-masing fungsi yaitu fungsi penjualan, bagian penjualan, bagian gudang dan bagian akuntansi.

b. Pengendalian Terhadap Sistem dan Program Pada PT. Suraco Jaya Abadi Motor fungsi perancangan sistem dan program sudah dilaksanakan dengan baik.Mereka menjalankan sistem 
yang disertai dengan pelatihan penggunaan sehingga dapat dipahami oleh bagian yang berwenang.

c. Pengendalian Terhadap Fasilitas Pengolahan Data Pengendalian terhadap fasilitas tersebut pada PT. Suraco Jaya Abadi Motor dilakukan dengan sangat hati-hati dengan membatasi akses terhadap fasilitas komputer hanya pada karyawan tertentu yang telah diberi otorisasi dalam hal ini orang yang ditunjuk oleh perusahaan, password yang digunakan hanya diketahui oleh yang berwenang dan adanya verifikasi otorisasi yang dilakukan oleh bagian yang telah ditentukan maka kemungkinan adanya manipulasi data tidak terjadi.

2. Pengendalian Transaksi dalam Aktivitas Penjualan pada PT. Suraco Jaya Abadi Motor

a. Pengendalian input pada PT. Suraco Jaya Abadi Motor dirancang untuk mencegah atau mendeteksi kekeliruan dalam tahap masukan dan pengolahan data. Perusahaan telah menjalankan prosedur input dengan pemasukan data yang hanya dilakukan oleh data entry khusus bagian penjualan. Dilakukan pula pemeriksaan pada keakuratan data serta kelengkapan serta validasi data. b. Pengendalian

pemrosesan Pengendalian pemrosesan ini dirancang untuk memberikan jaminan bahwa pemrosesan telah sesuai spesifikasi yang telah ditentukan dan tidak ada data yang tidak tepat yang dimasukkan ke jalur pemrosesan.

c. Pengendalian Output Pengendalian tersebut dirancang oleh PT. Suraco Jaya Abadi Motor untuk memastikan bahwa hasil pemrosesan sudah lengkap, akurat dan telah didistribusikan secara memadai. Prosedur output tersebut yaitu pendistribusian data telah sesuai dengan kebutuhan pihak tertentu karena tidak semua orang dalam organisasi memerlukan laporan yang sama, sehingga hanya orang yang berhak menerima laporan saja yang harus diberi laporan.

Dalam melakukan penelitian untuk mengetahui apakah sistem informasi akuntansi penjualan sudah berjalan efektif maka pengendalian intern penjualan pada suatu perusahaan juga sangat dibutuhkan agar tidak terjadi kecurangan dan kesalahan pada sistem yang telah diterapkan oleh PT. Suraco Jaya Abadi Motor, maka penulis melakukan penelitian mengajukan beberapa pertanyaan mengenai komponen-komponen sistem 
pengendalian intern kepada karyawan PT. Suraco Jaya Abadi Motor mengenai komponen sistem pengendalian intern.

1. Lingkungan Pengendalian

PT. Suraco Jaya Abadi Motor telah .melakukan fungsi yang jelas dan telah menempatkan karyawan perusahaan pada bagiannya masing-masing sesuai dengan kedudukannya didalam struktur organisasi serta sesuai dengan ijazah dan keahlian yang dimiliki karyawan. Dan dengan adanya struktur organisasi yang memisahkan tugas dan tanggung jawab mereka secara fungsional dan juga dengan adanya pemisahan fungsi pada penjualan dan fungsi pencatatan.

2. Penafsiran resiko

Dalam melakukan penilaian terhadap memungkinkan adanya resiko terutama dalam penjualan kreditnya dan apabila terjadi maka akan dilakukan peninjauan yang seharusnya, khususnya pada penjualan kredit misalnya dalam memberikan kredit motor pada pelanggan. Mengenai dampak-dampak dalam kemajuan teknologi PT. Suraco Jaya Abadi Motor mengenai penafsiran resiko untuk pelaporan keuangan telah diidentifikasi dan dianalisis terhadap resiko yang relevan dengan penyusunan laporan keuangan.

3. Aktivitas pengendalian
Bagian program mengenai sistem pada PT. Suraco Jaya Abadi Motor sudah memadai misalnya jika terjadi kesalahan pemrosesan dan program sistem secara otomatis akan menampilkan pesan error. Dan jika data yang diinput belum lengkap, maka sistem secara otomatis memberikan informasi data mana yang belum lengkap. Dan apabila program bermasalah maka pihak perusahaan akan melakukan perbaikan terhadap program tersebut.

Pada PT. Suraco Jaya Abadi Motor fungsi pengendalian terhadap sistem dan prosedur telah memadai. Para karyawan dapat menjalankan sistem pada masingmasing bagian sehingga dapat memperlambat aktivitas perusahaan diantaranya bagian penjualan telah melakukan peninjauan rutin dan berkala setiap transaksi yang berkaitan dengan penjualan. Setiap transaksi penjualan yang terjadi memiliki dokumen-dokumen yang dapat dijadikan bukti informasi bagi pihak manajemen. Otorisasi dokumen oleh pejabat berwenang telah dijalankan guna menghindari kesalahan atau kecurangan dalam pencatatan dan telah terdapat pemisahan fungsi pada bagian penjualan untuk memperlancar jalannya aktivitas perusahaan.

4. Informasi dan komunikasi

Pihak manajemen PT. Suraco Jaya Abadi Motor selalu menginformasikan 
dan mengkomunikasikan apabila terjadi permasalahan baik mengenai permasalahan penjualan kredit ataupun berupa pengumuman selalu diberitahukan kepada seluruh karyawan. Terdapat komunikasi antar setiap bagian seperti adanya kenaikan gaji atau motor motif baru keluar dan harga-harga motor dengan cara dibagikan brosur atau pemberitahuan ditempelkan di dinding.

\section{Pengawasan}

Untuk menghindari kesalahan dan hal-hal yang tidak dinginkan, perusahaan melakukan pengawasan dalah hal control terhadap omset setiap hari, tiap bulan selalu dilaporkan pada pihak manajer dan pusat. Berdasarkan dari uraian yang telah penulis lakukan diatas dengan demikian dapat disimpulkan bahwa sistem pengendalian intern penjualan pada PT. Suraco Jaya Abadi Motor telah memadai informasi penjualan dalam bentuk laporan-laporan yang dihasilkan oleh bagian penjualan informasi dapat membantu manajemen dalam pengambilan keputusan khususnya pada bagian penjualan.

\section{KESIMPULAN DAN SARAN}

\section{Kesimpulan}

Berdasarkan hasil penelitian mengenai sistem informasi akuntansi penjualan yang berdasarkan teori-teori tentang sistem informasi akuntansi penjualan, maka penulis dapat menarik kesimpulan bahwa sistem informasi akuntansi penjualan pada PT. Suraco Jaya Abadi Motor telah berjalan dengan sangat efektif simpulan ini diambil berdasarkan hasil perhitungan jawaban kuesioner atas pernyataan variabel menghasilkan jumlah sebesar $88.64 \%$

\section{Saran}

Berdasarkan dari hasil penelitian yang penulis peroleh, maka disarankan sebaiknya PT. Suraco Jaya Abadi Motor tetap mempertahankan sistem dan prosedur yang telah diterapkan dalam perusahaan, dan pada bagian tertentu sebaiknya menggunakan sistem komputer yang terbaru agar semakin memaksimalkan sistem informasi penjualan pada perusahaan.

\section{DAFTAR PUSTAKA}

Andreas. 2006. Analisis Sistem Informasi Akuntansi Penjualan terhadap Penurunan Tingkat Piutang Tak Tertagih. Tasikmalaya

Diana, Anastasia., Setiawati, Lilis. 2011. Sistem Informasi Akuntansi. CV Andi Offset.Yogyakarta.

Diana. 2013. Analisis Sistem Informasi Akuntansi terhadap Fungsi Penjualan pada CV. Agus Jaya Motor. Makassar 
George H. Bodnar, William S. Hoopwood. 2009. Sistem Informasi Akuntansi. Amir Abadi Jusuf

Hery. 2009. Teori Akuntansi, Kencana Prenada Media Group, Jakarta.

2013. Teori Akuntansi. Lembaga Penerbit Fakultas Ekonomi Universitas Indonesia. Jakarta

James A Hall. 2009. Accounting Information System. Salemba 4. Jakarta

Kaelan. 2012. Metode Penelitin Kualitatif. Paradigma.Yogyakarta

Krismiaji. 2005. Sistem Informasi Akuntansi Edisi 2. UPP AMP YKPN. Yogyakarta

Mardi. 2011. Sistem Informasi Akuntansi. Graha Indonesia. Bogor

Marshall B., Romney Daul., John Steinbart. 2011. Sistem Informasi Akuntansi Edisi 9. Salemba Empat. Jakarta

Samiaji Sarosa. 2009. Sistem Informasi Akuntansi.PT Gramedia Widyasarana. Indonesia

Sugiyono. 2009. Metodologi Penelitian Pendidikan, Pendekatan Kuantitatif, Kualitatif dan R\&D, (online). Bandung. Diakses 15 Desember 2015
Sujarweni Wiratna. 2015. Sistem Informasi Akuntansi. Pustaka Baru Press. Yogyakarta

Sutabri Tata. 2004. Sistem Informasi Akuntansi. Andi.yogyakarta

Widjayanto. 2001. Sistem Informasi Akuntansi. Erlangga. Jakarta 